\title{
Pengaruh Ekstrak Pakis (Diplazium esculentum SWARTZ) Terhadap Anatomi Tanaman Cabai Rawit (Capsicum frutescens $\mathrm{L}$ )
}

\author{
The Effect of Fern Extract (Diplazium esculentum SWARTZ) on the Anatomy of \\ Cayenne Pepper (Capsicum frutescens $\mathrm{L}$ )
}

\author{
Bertiana Jelimat $^{1}$, Ngadiani $^{2}$ \\ Prodi Biologi Fakultas Sains Teknologi Universitas PGRI Adi Buana Surabaya \\ Email: bertinjnr@gmail.com¹, ngadiani@unipasby.ac.id ${ }^{2}$
}

\begin{abstract}
Abstrak
Ekstrak pakis adalah tanaman yang mengandung hormon giberelin. Zat pengatur tumbuh adalah hormon sintetis dari luar tubuh tanaman. Hormon giberelin mempunyai fungsi untuk merangsang perkecambahan, pertumbuhan akar, tunas daun dan menunda penuaan pada daun. Penelitian ini bertujuan untuk mengetahui pengaruh pemberian ekstrak pakis sayur terhadap anatomi tanaman cabai rawit berupa kerapatan stomata dan indeks stomata.Penelitian ini dimulai pada bulan Maret-Mei di green house Universitas PGRI Adi Buana Surabaya. Perlakuan ekstrak pakis sayur P0 (0\%), P1 (5\%), P2 (10\%) dan P3 (15\%). Penelitian ini menggunakan Rancangan Acak Lengkap dengan 4 taraf perlakuan dan 6 kali ulangan. Pemberian ekstrak pakis pada tanaman cabai rawit diberikan pada umur tanam 1 bulan, selama 4 kali dengan pemberian 1 minggu sekali. Data hasil penelitian kemudian dianalisis dengan menggunakan spss 16.0 analisis varians satu arah. Data berpengaruh signifikan akan dilanjutkan uji lanjut yakni uji Duncan. Hasil penelitian membuktikan bahwa pemberian ekstrak daun pakis sayur menunjukan pengaruh yang nyata $(\mathrm{P}<0,05)$ pada kerapatan somata dan indeks stomata daun cabai rawit. Hasil uji Duncan menunjukan bahwa perlakuan P3 (15\%) berbeda nyata dibandingkan dengan perlakuan P0 (0\%), P1 (5\%), P2 (10\%).
\end{abstract}

Kata kunci: Ekstrak daun pakis sayur, indeks stomata, kerapatan stomata daun cabai rawit.

\begin{abstract}
Fern extract is a plant that contains the hormone gibberellin. Growth regulators are synthetic hormones from outside the plant body. The hormone gibberellin has a function to stimulate germination, root growth, leaf shoots and delay leaf aging. This study aims to determine the effect of vegetable fern extracts on the anatomy of cayenne pepper plants in the form of stomata density and stomatal index. This research was started in March-May at the green house of the PGRI Adi Buana University Surabaya. The treatments of vegetable fern extract were PO $(0 \%)$, P1 (5\%), P2 (10\%) and P3 (15\%). This study used a completely randomized design with 4 levels of treatment and 6 replications. Giving fern extract to cayenne pepper plants is given at the age of 1 month of planting, for 4 times with the provision of 1 week. The research data were then analyzed using one-way analysis of variance (ANOVA). Data that has a significant effect will be followed by a further test, namely the Duncan test. The results proved that giving vegetable fern leaf extract showed a significant effect $(P<0.05)$ on somata density and stomata index of cayenne pepper leaves. Duncan's test results showed that P3 treatment (15\%) was significantly different compared to treatment P0 (0\%), P1 (5\%), P2 (10\%).
\end{abstract}

Keywords: Vegetable fern leaf extract, stomatal index, stomata density of cayenne pepper.

\section{PENDAHULUAN}

Cabai rawit (Capsicum frutescens $\mathrm{L}$. ) adalah tanaman holtikultura yang berasal dari jenis sayuran yang mempunyai buah kecil dengan rasa yang pedas dan merupakan jenis sayuran yang banyak disukai di masyarakat. (Kmana, 2002) Tanaman ini memiliki banyak kegunaan terutama pada buahnya, yakni sebagai bumbu masak, bahan campuran industri makanan, dan sebagai bahan kosmetik. Bukan hanya buahnya, jenis lain dari tanaman ini seperti batang, daun, ataupun akarnya juga bisa dimanfaatkan sebagai obat-obatan (Ashari,1995).

Produksi tanaman cabai rawit ini dari tahun ke tahun terus bertambah. Namun mengalami penurunan ditandai dengan produksi tahun 2009 sebesar 591.294 ton, namun pada tahun 2010 produksinya hanya 521.704 ton. (Deptan, 2011). Meskipun begitu, harga cabai rawit di pasaran juga seringkali lebih tinggi dari pada jenis cabai pada umumnya. Penyebab berkurangnya 
produktivitas salah satunya pengelolahan tanah, pemberian pupuk dan zat pengatur tumbuh (BPS, 2016).

Peningkatan produktivitas tanaman dapat dilakukan dengan pemberian bahan organic pada media tanam. Bahan tersebut mempunyai peran penting dalam menentukan kemampuan tanah untuk mendukung tanaman. Selain itu pemakaian zat pengatur tumbuh juga dapat mendorong pertumbuhan untuk menambah produksi cabai (Prajnanta, 2011).

Salah satu tanaman yang dapat digunakan sebagai Zat pengatur tumbuh yaitu tanaman pakis (Diplazium esculentum Swartz.), karena tanaman tersebut mengandung ZPT giberelin yang dapat berfungsi untuk merangsang pembelahan sel, pemanjangan sel sehingga terjadi penambahan ukuran buah, batang, dan menunda penuan pada daun (Salibury dan Ross, 1985).

Tujuan dari penelitian ini untuk mengetahui pengaruh ekstrak pakis terhadap anatomi tanaman cabai rawit.

\section{METODE PENELITIAN}

Penelitian ini dilakasanakan di Laboratorium Biologi Dasar dan green house, Fakultas Sains dan Teknologi Universitas PGRI Adi Buana Surabaya.

Penelitian ini metode yang digunakan adalah metode Rancangan Acak Lengkap (RAL) yang perlakuannya terdiri dari 4 perlakuan dan 6 kali ulangan dengan konsentrasi $0 \%$, $5 \%, 10 \%$, dan $15 \%$. Penelitian terdiri dari beberapa tahap yaitu:

\section{Persiapan benih}

Pemilihan benih yang baik dengan cara direndam dalam air selama 20 menit dan dipilih benih yang tenggelam, agar diperoleh benih yang utuh dan tidak cacat.

\section{Persemaian}

Proses penyemaian dapat dilakukan dengan cara ditaburkan pada baris pot tray persemaian media tanah. Persemaian dilakukan 25 hari atau telah memiliki 3-4 daun benar, batang kokoh serta perakaran berkembang baik dan disiram tiap pagi dan tanpa pemberian pupuk sampai benih cabai rawit siap untuk dipindahkan ke polybag ukuran $30 \times 30 \mathrm{~cm}$

\section{Pengolahan Lahan}

Menyiapkan media tanam dan polybag. Tindakan tersebut yaitu tanah dan pupuk dengan perbandingan 1:1. Setelah media tanam sudah tercampur, media tanam dibiarkan selama 7 hari sebelum digunakan. Hal tersebut bertujuan untuk mendapatkan $\mathrm{pH}$ ideal, agar tidak terjadi pertumbuhan yang terhambat.

\section{Pembuatan Ekstrak Pakis Sayur}

Daun pakis sayur yang sudah disiapkan dipotong kecil-kecil kemudian dikeringkan dalam suhu ruangan selama 3-4 hari sampai daun pakis kering, kemudian di blender dijadikan serbuk.kemudian di timbang sebanyak 100 gr, setelah ditimbang serbuk daun pakis di bungkus dengan kain berwarna putih (kain saring) Setelah itu dimaserasi dengan alkohol $70 \%$ selama 3 hari. Kemudian di destilasi dan dilanjut pengovenan dengan suhu 70$80^{\circ} \mathrm{C}$. Hasil yang diperoleh tersebut disimpan dalam wadah tertutup.

\section{Penanaman}

Penanaman tanaman cabai rawit dilakukan pada polybag yang berukuran $30 \mathrm{x} 30 \mathrm{~cm}$. Langkah pertama yaitu memindah bibit tersebut dengan cara dicabut. Caranya, siram persemaian dengan air agar media tanam menjadi lunak. lalu cabut tanaman dengan hatihati jangan sampai akar tanaman putus atau rusak. Kemudian masukan bibit cabai tersebut pada polybag, yang sudah diisi tanah secara lurus pada lubang tanaman. jangan sampai bengkok. atau terlipat. Atur kedalaman lubang tanam sesuai dengan panjang akar.

\section{Pemeliharan dan Perawatan}

Bibit cabai yang sudah pindah ke polybag harus dirawat dengan baik. Pemeliharaan tanaman cabai rawit dalam polybag relativ murah, karena kesehatan tanaman lebih diperhatikan agar tidak 
terjadi penyakit atau hama masuk melalui akar. Penyaingan gulma juga perlu agar tidak terjadi perebutan nutrisi dengan tanaman yang mengganggu.

\section{Perlakuan Pemberian ZPT}

Pemberian ekstrak pakis sayur dapat dilakukan dengan cara menyiramkan dengan masing-masing perlakuan yang akan di teliti sesuai dengan konsentrasi yang disiramkan pada setiap perlakuan sebagai berikut: P0 (0\%), P1(5\%), P2 (10\%), P3 (15\%). Pemberian ZPT dilakukan satu minggu setelah persemaian dipindah ke polybag sebanyak $100 \mathrm{ml}$ caranya ekstrak pakis dituangkan pada tanah. Pemberian ekstrak pakis sayur seterusnya dilakukan setiap satu kali dalam seminggu hingga siap untuk di amati anatomi tanaman tersebut.

\section{Variabel Pengamatan}

Variabel yang diamati pada penelitian ini kerapatan stomata dan indeks stomata daun cabai rawit. Adapun metode yang dipakai untuk mengamati stomata dipermukaan daun adalah metode replica (Haryanti,2010). Pengamatan daun dilakukan dibawah mikroskop dengan menggunakan optilab.

Cara kerja:

Metode pembuatan preparat untuk melihat stomata adalah metode replica sbb:

1. Daun- daun yang sudah diambil permukaan atas dan bawahnya dibersihkan ditiup atau dengan tissue untuk menghilangkan debu/kotoran.

2. Olesi dengan kutek, dibiarkan 10 menit, supaya kering
3. Olesan yang sudah kering ditempeli isolasi dan diratakan

4. Isolasi dikelupas/diambil pelanpelan, lalu tempelkan pada gelas benda

5. Diratakan dan diberi label pada sebelah kiri dengan keterangan jenis tanamannya.

6. Pengamatan stomata per bidang pandang mengguakan mikroskop dengan perbesaran $(10 \mathrm{x} 40)$.

Hasil Pengamatan dari parameter Anatomi di analisis menggunakan rumus:

Kerapatan $\sum s$ stomata =

Satuan luas bidang pandang

Indeks stomata $=\frac{\sum S}{\Sigma S+\sum E}$

Keterangan : $\sum S=$ Jumlah Stomata $\sum E=$ Jumlah Epidermis

Keterangan :Luas bidang pandang $=$ $\pi r^{2}$ (Gan et al.,2010)

\section{Analisis Data}

Hasil penelitian dianalisis menggunakan analisis SPSS dengan metode analisis varians. Hasil analisis varians yang berpengaruh atau berbeda nyata dilanjutkan dengan uji DUNCAN.

\section{HASIL DAN PEMBAHASAN}

Hasil penelitian menunjukan bahwa pemberian zat pengatur tumbuh ekstrak daun pakis sayur (Diplazium esculentum Swartz) dengan berbagai konsentrasi berpengaruh signifikan $(\mathrm{P}<0,05)$ pada anatomi tanaman cabai rawit (Capsicum frutescens $\mathrm{L}$. 


\section{Analisis Kerapatan Stomata}

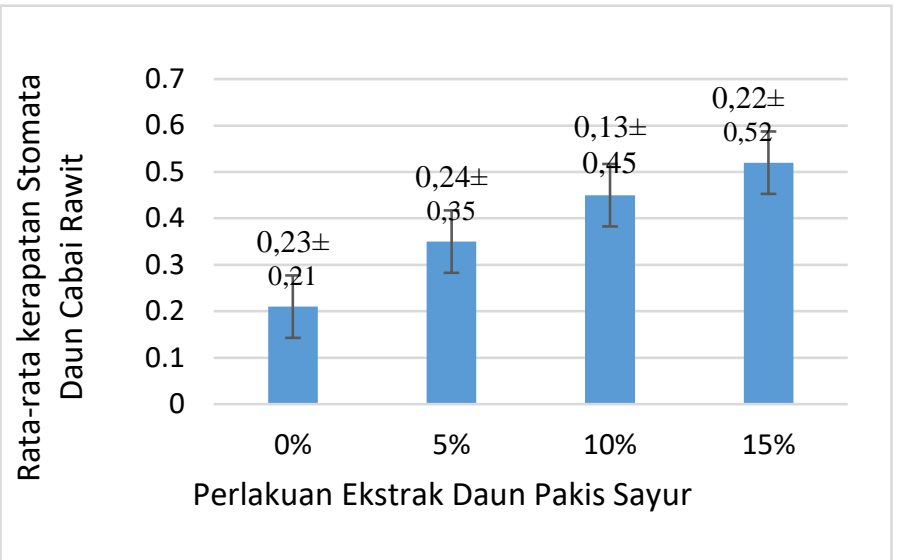

Gambar 1. Kerapatan stomata daun cabai rawit (Capsicum frutescens L.) setelah diberikan perlakuan Zat pengatur tumbuh ekstrak daun pakis sayur (Diplazium esculentum Swartz)

Pada hasil analisis varians yang dilakukan dan dilanjut dengan uji Duncan Zat pengatur tumbuh ekstrak daun pakis sayur dapat meningkatkan kerapatan stomata pada tingkat konsentrasi $15 \%$ sebesar 0,52. Pada gambar diagram 1. dapat diketahui bahwa setiap perlakuan yang memiliki konsentrasi berbeda berpengaruh terhadap kerapatan stomata. Kerapatan stomata daun cabai rawit pada konsentrasi $0 \%$ ekstrak daun pakis sayur sebesar 0,21 dan pada konsentrasi 5\% ekstrak pakis sayur sebesar 0,35 pada konsentrasi $10 \%$ ekstrak pakis sayur sebesar 0,45 dan tertinggi terdapat pada konsentrasi $15 \%$. Hal ini membuktikan bahwa ekstrak pakis sebagai zat pengatur tumbuh alami bisa meningkatkan kerapatan stomata pada daun cabai rawit. Bisa dikatakan semakin tinggi konsentrasi yang di berikan maka akan semakin tinggi pula tingkat kerapatan stomata daun cabai rawit.

Stomata adalah bagian penting dalam proses fotosintesis dan juga transpirasi pada tanaman. Stomata berfungsi sebagai tempat pertukaran $\mathrm{CO} 2$ pada daun untuk proses fotosintesis dan sebagai tempat penguapan air dalam proses transpirasi. Hasil penelitian yang dilakukan oleh Arista dkk, (2015) pada tanaman tebu membuktikan bahwa pemberian Zat pengatur tumbuh ekstrak pakis bisa meningkatkan kerapatan stomata yang menyebabkan jumlah stomata semakin banyak, sehingga dapat meningkatkan laju transpirasi dan penyerapan karbon dioxide untuk fotosintesis.

Meningkatnya jumlah stomata menyebabkan kerapatannya juga meningkat sehingga terjadi peningkatan jumlah stomata tanaman cabai rawit pada satuan luas tertentu. Peningkatan jumlah stomata bisa dikatakan sebagai bentuk penyusuaian tanaman terhadap lingkungan disekitar akibat dari kebutuhan evaporasi yang sangat banyak. Selain itu, pemberian ekstrak pakis juga bisa membuat sistem perakaran menjadi lebih baik, sehingga penyerapan unsur hara menjadi lebih optimal. Unsur hara tersebut bisa dipakai dalam proses metabolisme pada tanaman sehingga bisa memacu pertumbuhan. Seperti pendapat Makarim dkk, (2015).

Menurut Hendaryono dan Wijayani 1994, ekstrak pakis sayur sebagai zat pengatur tumbuh merupakan hormon yang berasal pada bagian luar dari tubuh. Beberapa faktor yang mengganggu keberhasilan pemakaian ZPT antara lain adalah dosis, kedewasaan tanaman, dan lingkungan. Pengaplikasian ZPT pada tanaman yang belum dewasa justru bisa menghambat pertumbuhannya, karena secara anatomi tanaman itu belum mampu berbunga. Faktor lingkungan adalah temperatur, kelembaban, curah hujan, cuaca, dan sinar sangat berpengaruh terhadap 
pemakaian ZPT. Bila kondisi lingkungan sesuai dengan kebutuhan tanaman, ZPT yang diaplikasikan akan dapat segera diserap oleh tanaman. Pemakaian dosis ZPT yang tepat bisa menghambat proses pembungaan tanaman. Dosis yang kurang atau berlebihan dapat menyebabkan pengaruh ZPT menjadi hilang, sedangkan dosis yang tinggi bisa menghambat pertumbuhan dan perkembangan tanaman (Endah, 2001).

\section{Analisis Indeks Stomata daun cabai rawit}

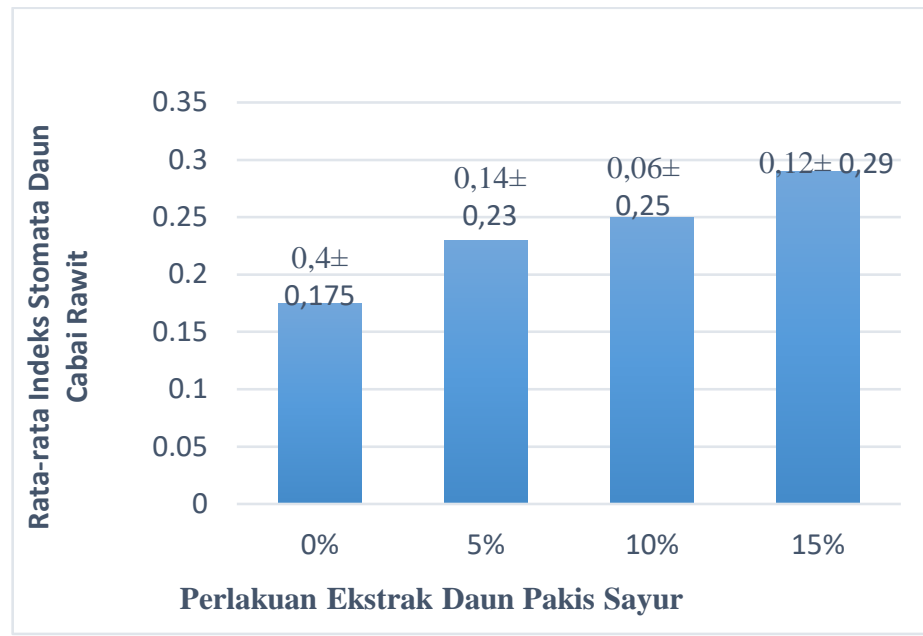

Gambar 2. Diagram indeks stomata daun cabai rawit (Capsicum frutescens L.) setelah diberikan perlakuan Zat pengatur tumbuh ekstrak daun pakis sayur (Diplazium esculentum Swartz)

Berdasarkan diagram diatas dapat diketahui bahwa setiap perlakuan dapat meningkatkan indeks stomata daun cabai rawit hal ini membuktikan bahwa semakin tinggi konsentrasi yang diberikan maka akan semakin banyak pula jumlah stomatanya. Pada perlakuan P0 (0\%) memiliki indeks stomata rata-rata sebesar 0,175 , pada perlakuan P1 (5\%) memiliki rata-rata indeks stomata sebesar 0,23, pada perlakuan P2 (10\%) mempunyai rata-rata indeks stomata sebesar 0,25, dan pada perlakuan P3 (15\%) mempunyai rata-rata indeks stomata sebesar 0,29 .

Berdasarkan hasil penelitian yang dilakukan dapat diketahui bahwa indeks stomata setiap perlakuan bisa meningkatakan indeks stomata daun cabai rawit yang berbeda-beda. Perlakuan yang paling optimum yaitu ekstrak pakis sayur pada konsentrasi P3 (15\%). Pada ekstrak pakis sayur konsentrasi $15 \%$ indeks stomatanya banyak karena semakin tinggi kandungan ekstrak pakis sayur yang diberikan dapat meningkatkan jumlah stomata serta sel epidermisnya sehingga indeks stomata daun cabai rawit semakin banyak. Dalam penelitian ini peneliti mengamati stomata epidermis bagian bawah daun cabai rawit. Jumlah stomata bagian bawah sangat banyak hal ini dikarenakan permukaan bawah daun tidak terkena cahaya matahari langsung sehingga tidak banyak stomata yang rusak akibat penyinaran yang sangat amat cekal. Selain itu, pada bagian bawah, lapisan pelindung yang melapisi epidermis sangat pipih atau bahkan tidak dilapisi oleh kutikula, sehingga tidak ada bahkan hanya sedikit penghambat untuk berlangsungnya proses transpirasi melewati stomata. Haryanti (2010).

Banyaknya jumlah daun maka semakin banyak juga jumlah stomata sehingga semakin besar transpirasinya, transpirasi bisa diartikan sebagai proses kehilangan air dalam bentuk uap air dari jaringan tumbuhan melalui stomata, banyaknya jumlah stomata maka tanaman 
mampu carbon dioxide dan menghasilkan oxygen. Distribusi stomata sangat berkaitan dengan kecepatan dan intensitas transpirasi pada daun, yakni contohnya letak satu sama lain dengan jarak tertentu dalam batas tertentu, maka semakin banyak pori-porinya semakin cepat pula penguapan. Jika lubanglubang tersebut terlalu berdekatan, maka evaporasi dari lubang yang satu bisa menghalangi evaporasi pada lubang dekatnya (Hariyanti, 2010). Meningkatnya jumlah stomata bisa membantu dalam hal penyerapan carbon dioxide untuk fotosintesis (Azmat et al., 2009 dalam Andini, 2011).

Proses transpirasi tersebut selain mengakibatkan penarikan air melawan gaya gravitasi bumi, juga panas matahari karena melalui proses transpirasi, terjadinya evaporasi air bisa membantu mengecilkan temperature pada tanaman. Selain itu, melalui proses transpirasi, tanaman juga akan sering memperoleh air yang cukup untuk melakukan fotosintesis supaya keberlangsungan hidup tanaman akan terus terjaga (Imiliyana, 2012)

\section{SIMPULAN DAN SARAN Simpulan}

Hasil penelitian menunjukan bahwa pemberian ekstrak daun pakis sayur (Diplazium esculentum Swartz) yang berbeda pada tanaman cabai rawit (Capsicum frutescens L.) berpengaruh terhadap kerapatan stomata dan indeks stomata daun cabai rawit pada perlakuan P3 $15 \%$ ekstrak daun pakis sayur.

\section{Saran}

Berdasarkan hasil penelitian disarankan menggunakan ekstrak daun pakis sayur dengan konsentrasi $15 \%$ untuk meningkatkan kerapatan stomata dan meningkatkan nilai indeks stomata daun cabai rawit. Selain itu dapat menjadikan pakis sayur sebagai alternatif zat pengatur tumbuh alami.

\section{DAFTAR PUSTAKA}

Andini, N. A. 2011. Anatomi Jaringan Daun dan pertumbuhan Tanaman Celosia cristata, Catharanthus roseus, dan Gomphrena globosa pada Lingkungan Udara Tercemar. (Skripsi). Institut Pertanian Bogor.

Haryanti, S. 2010. Jumlah dan Distribusi Stomata pada Daun Beberapa Spesies Tanaman Dikotil dan Monokotil. Jurnal Buletin Anatomi dan Fisiologi . Vol. XVIII, No. 2.

Imiliyana, A. 2012. Penghijauan butuh transpirasi

http://aufariz.blogspot.com/2011/01/s ebelum-menghijaukan-

kitabutuh.html. diakses tanggal 7-22020.

Kmana, R., 2002, Usaha Tani Cabai Rawit, Kanisius, Yogyakarta

Makarim, A. K., E. Suhartatik, dan A. Kartohardjono. 2007. Silikon: Hara Penting pada Sistem Produksi Padi. Iptek Tanaman Pangan. 2(2):195-204.

Prajnanta F. 2007. Mengatasi Permasalahan Bertanam Cabai Hibrida Secara Intensif. Agromedia Pustaka. Jakarta.

Prajnanta, F., 2011, Mengatasi Permasalahan Bertanam Cabai, Penebar Swadaya, Jakarta

Suyitno. 2012. Perbandingan jumlah stomata pada bagian abaksial dan adaksial.

http://www.pertanian.untagsmd.ac.id/ wpcontent/uploads/2012/06/Proses T ranspirasi_PadaTanaman Bab IX.pdf. (diakses pada tanggal 9 Desember 2013)

Salisbury, Frank B dan Cleon W Ross. 1995. Fisiologi Tumbuhan Jilid 1. Bandung: ITB. 